Indonesian Journal of Medicine (2019), 4(4): 300-312

https://doi.org/10.26911/theijmed.2019.04.04.02

\title{
Factors Associated with Diabetic Peripheral Neuropathy among Patients with Type 2 Diabetes Mellitus in Surakarta, Central Java
}

\author{
Akhmad Azmiardi'), Didik Tamtomo²), Bhisma Murti') \\ ${ }^{1)}$ Masters Program in Public Health, Universitas Sebelas Maret \\ ${ }^{2)}$ Faculty of Medicine, Universitas Sebelas Maret
}

\begin{abstract}
Background: Peripheral neuropathy is the most common chronic complication and often occurs in diabetes mellitus. Peripheral neuropathy can cause morbidity, decreased quality of life,and mortality. This study aimed to analyze the determinants of peripheral neuropathy in patients with type 2 diabetes mellitus in Surakarta, Central Java.

Subjects and Method: This study was an observational analytic with cross sectional design. This study was conducted at Surakarta Regional Hospital, Central Java on July 2019. A total of 200 type 2 diabetes mellitus outpatients was selected by simple random sampling. The dependent variable was peripheral neuropathy. The independent variables were age, education level, income, selfefficacy, diet, medication adherence, physical activity, health literacy, duration of illness, and fasting blood sugar. Peripheral neuropathy was measured using the Michigan Neu-black Screening Instrument (MNSI). Other variable data were obtained using questionnaires. Analysis of data used multiple logistic regression.

Results: The risk of peripheral neuropathy increased with age of $\geq 55$ years $(\mathrm{b}=3.61 ; 95 \% \mathrm{CI}=$ 1.51 to $5.70 ; p=0.001)$, duration of illness $\geq 5$ years $(b=2.78 ; 95 \% \mathrm{CI}=0.51$ to $5.04 ; \mathrm{p}=0.016)$, and fasting sugar $\geq 110 \mathrm{mg} / \mathrm{dL}(\mathrm{b}=1.64 ; 95 \% \mathrm{CI}=-0.01$ to $3.03 ; \mathrm{p}=0.052)$. The risk of peripheral neuropathy decreased with education level $\geq$ senior high school $(b=-2.41 ; 95 \% \mathrm{CI}=-4.31$ to -0.51 ; $\mathrm{p}=0.013)$, income $\geq \mathrm{Rp} \mathrm{1,800,000}(\mathrm{b}=-1.58 ; 95 \% \mathrm{CI}=-3.12$ to $-0.04 ; \mathrm{p}=0.044)$, high self-efficacy $(\mathrm{b}=-1.67 ; 95 \% \mathrm{CI}=-3.26$ to $-0.07 ; \mathrm{p}=0.040)$, controlled diet $(\mathrm{b}=-1.89 ; 95 \% \mathrm{CI}=-3.64$ to $-0.14 ; \mathrm{p}=$ 0.034), high medication adherence $(b=-2.34 ; 95 \% \mathrm{CI}=-4.13$ to $-0.56 ; \mathrm{p}=0.010)$, high physical activity $(\mathrm{b}=-2.33 ; 95 \% \mathrm{CI}=-4.17$ to $-0.49 ; \mathrm{p}=0.013)$, and high health literacy $(\mathrm{b}=-1.52 ; 95 \% \mathrm{CI}=-$ 3.18 to $0.14 ; \mathrm{p}=0.073)$.

Conclusion: The risk of peripheral neuropathy increases with age of $\geq 55$ years, duration of illness $\geq 5$ years, and fasting blood sugar $\geq 110 \mathrm{mg} / \mathrm{dL}$. The risk of peripheral neuropathy decreases with a high education level, income of $\geq 1,800$,000, high self-efficacy, controlled diet, high medication adherence, high physical activity, and high health literacy.
\end{abstract}

Keywords: peripheral neuropathy, diabetes

\section{Correspondence:}

Akhmad Azmiardi. Masters Program in Public Health, Universitas Sebelas Maret, Jl. Ir. Sutami 36 A, Surakarta 57126, Central Java, Indonesia. Email: aazmiardi@gmail.com.Mobile: 085245412021

\section{BACKGROUND}

Diabetes mellitus (DM) is a very critical public health problem. A total of 425 million people suffer from diabetes. Indonesia ranks 6th in the world with 10.3 million DM sufferers (IDF, 2017). Diabetes ranks second as the biggest disease in Central Java with a prevalence of $19.22 \%$
(Health Office of Central Java, 2017). Based on Surakarta's health profile diabetes is included in the 10 largest diseases in Surakarta (Surakarta health service, 2018).

Diabetes progressively progresses and is associated with a number of complications such as retinopathy, nephropathy, and neuropathy (Forbes and Cooper, 2013). 
Neuropathy is a disorder of nerve activity throughout the body and can change autonomic, motoric, and sensory functions (IDF, 2017).

Peripheral neuropathy is the most common complication in DM. Peripheral neuropathy is a nerve disorder that affects the nerves of the distal limbs, especially the legs. Peripheral neuropathy can cause morbidity such as diabetic cancer, ulceration, infection, and amputation (IDF, 2017). About 8\% of peripheral neuropathies occur in patients newly diagnosed with DM and more than $50 \%$ of peripheral neuropathies occur in patients who have been diagnosed long ago (Deli et al., 2013).

At least 200 million people with DM around the world have neuropathy. About 20 million Americans are estimated to currently have pre-diabetic neuropathy, type 1 diabetes, or type 2 diabetes (Feldman et al., 2017).

According to Soewondo (2013) about diabetes management in Indonesia, the prevalence of diabetes in Indonesia is quite high by $78 \%$ (Soewondo et al., 2013).

Risk factors for peripheral neuropathy include duration of diabetes, hyperglycemia, aging, hyperglycemia such as high fasting blood sugar, obesity, and low physical activity (Papanas and Ziegler, 2015) . The highest prevalence of neo-poultry is in people with poor blood glucose control (Callaghan et al., 2012).

Peripheral neuropathy also has a huge impact on the decreased quality of life of patients with DM. This is mainly due to weaknesses, ataxia, injury and other conditions (Vinik et al., 2013). DM patients with peripheral neuropathy also require more health care costs than DM patients without complications (Juster-Switlyk and Smith, 2016).

The high prevalence of peripheral neuropathy in type $2 \mathrm{DM}$ is an important problem that must be resolved immediately using a model approach that is able to assess various factors. This study aims to analyze the determinants of peripheral neuropathy in type 2 diabetes mellitus patients.

\section{SUBJECTS AND METHOD \\ 1. Design of the Study \\ This type of study was an observational analytic study with cross sectional design. This study was conducted in July 2019 at Surakarta Regional Hospital, Central Java.}

\section{Population and Sample}

The population in this study were all type 2 diabetes mellitus outpatients in Surakarta Regional Hospital. A total of 200 patients were selected using simple random sampling technique.

\section{Variables of the Study}

The dependent variable in this study was peripheral neuropathy. The independent variables were age, education level, income, self-efficacy, diet, medication adherence, physical activity, health literacy, duration of illness, and fasting blood sugar.

\section{Operational Definition of Variables} Peripheral neuropathy. Peripheral neuropathy was a disorder of sensory nerve activity that affected the nerves of the distal limbs, especially the feet caused by diabetes mellitus.

Age. Age was the time of the respondent's existence from the beginning of birth until the time this study was conducted.

Education. The level of education was the highest level of formal education or the highest equivalent ever achieved by subjects of the study.

Income. Income was the average of maximum wage received by both formal and informal subjects, husband or wife within a period of one month based on the minimum wage in Surakarta. 
Self-efficacy. Self-efficacy was the belief or confidence of subjects of the study regarding their ability to perform DM type 2 self-care behavior.

Diet. Diet was a statement of the subject on behavior or actions in carrying out nutritional therapy by medical personnel whether it is in accordance with the type, quantity, and eating schedule recommended in the self-care management of type 2 DM patients.

Medication Adherence. Adherence to a medication was a statement of the subject's behavior in receiving treatment therapy provided by health care providers. This was consisted of barriers related to drugs, barriers about the health care system, intentional barriers by subjects, and unintentional barriers by subjects of the study.

Physical Activity. Physical activity was the subject's statement about behavior in carrying out activities or physical exercises consisting of time spent while walking outdoors, time spent in practicing sports, and contributions to household chores.

Health Literacy. Health literacy was the subject's ability to find, understand, and assess health information obtained in daily life.

The duration of illness. The duration of illness was a statement of the subject for the duration or time of illness that had been suffered by the subject, starting from the time it was diagnosed by a doctor to when asked by the researcher.

Fasting Blood Sugar. Fasting blood sugar was a blood sugar level that was measured after the subject has been fasting for approximately 8 hours and stated in $\mathrm{mg} / \mathrm{dL}$ units.

\section{Instruments of the Study}

Peripheral neuropathy data were obtained using Michigan Neuropathy Screening Instrument (MNSI). Other variable data were collected using questionnaires. The questionnaires consisted of favorable and unfavorable questions. The instrument in the study used questionnaires that had been tested for validity and reliability.

\section{Data Analysis}

Univariate analysis was to see the frequency distribution and percentage characteristics of subjects of the study for categorical data, while continuous data was to see N, Mean, SD, Min, and Max. Bivariate analysis used Chi-square test and Odds Ratio. Multivariate analysis used multiple logistic regression.

\section{Research Ethics}

Research ethics included informed consent, anonymity, confidentiality, and ethical clearance. Ethical eligibility in this study came from the Medical Research Ethics Commission of the Faculty of Medicine, Universitas Sebelas Maret, Central Java, with number: 130/UN27.06/KEPK / 2019

\section{RESULTS \\ 1. Sample Characteristics}

Table 1 shows the average of subjects aged 55.92 years with a minimum age by 40 years and a maximum age by 76 years. The average income of $R p 1,595,000$ with the lowest income of $\mathrm{Rp} 400,000$ and the highest $\mathrm{Rp} 4,500,000$. The average health literacy value was 11.57 with the lowest score was 3 and the highest was 21. The majority of self-efficacy had a value by 7.42 with the lowest value was 3 and the highest was 15 . The average of medication adherence was 6.62 with the lowest value of 3 and the highest 13 . The average of diet value was 14.82 with the lowest value by 4 and the highest by 32 . The majority of physical activity had a value by 17.41 with the lowest value by 8 and the highest by 30 . The average duration of illness was 5.49 years with the lowest duration by 1 year and the highest by 15 years. Fasting blood sugar 
averaged was $143.66 \mathrm{mg} / \mathrm{L}$ with the lowest value by $85 \mathrm{mg} / \mathrm{dL}$ and the highest by 350 $\mathrm{mg} / \mathrm{dL}$. The average value of peripheral neuropathy was 10.79 with the lowest value by 4 and the highest by 19 .

Table 1. Univariate Analysis (Continuous Data)

\begin{tabular}{lccccc}
\hline Variable & n & Mean & SD & Min. & Max. \\
\hline Age & 200 & 55.92 & 9.03 & 40 & 76 \\
Income & 200 & 15.95 & 8.94 & 4 & 45 \\
Health literacy & 200 & 11.57 & 6.49 & 3 & 21 \\
Efficacy & 200 & 7.42 & 3.17 & 3 & 15 \\
Mediation Adherence & 200 & 6.62 & 2.93 & 3 & 13 \\
Diet & 200 & 14.82 & 7.79 & 4 & 32 \\
Physical Activity & 200 & 17.41 & 7.40 & 8 & 30 \\
Duration of illness & 200 & 5.49 & 3.11 & 1 & 15 \\
Fasting blood sugar & 200 & 143.66 & 55.54 & 85 & 350 \\
Peripheral neuropathy & 200 & 10.79 & 4.77 & 4 & 19 \\
\hline
\end{tabular}

Table 2. Univariate Analysis (Dichotomous Data)

\begin{tabular}{|c|c|c|c|}
\hline Variable & Criteria & Frequency(n) & Percentage (\%) \\
\hline \multirow[t]{2}{*}{ Age } & $<55$ years & 97 & 48.5 \\
\hline & $\geq 55$ years & 103 & 51.5 \\
\hline \multirow{2}{*}{ Sex } & Male & 68 & 34.0 \\
\hline & Female & 132 & 66.0 \\
\hline \multirow{2}{*}{ Education } & Low & 121 & 60.5 \\
\hline & High & 79 & 39.5 \\
\hline \multirow{2}{*}{ Income } & $<\operatorname{Rp} 1,800,000$ & 113 & 56.5 \\
\hline & $\geq \operatorname{Rp} 1,800,000$ & 87 & 43.5 \\
\hline \multirow{2}{*}{ Health literacy } & Low & 110 & 55.0 \\
\hline & High & 90 & 45.0 \\
\hline \multirow[t]{2}{*}{ Self-efficacy } & Low & 112 & 56.0 \\
\hline & High & 88 & 44.0 \\
\hline \multirow[t]{2}{*}{ Medication Adherence } & Disobedient & 116 & 58.0 \\
\hline & Obedient & 84 & 42.0 \\
\hline \multirow[t]{2}{*}{ Diet } & Uncontrolled diet & 107 & $53 \cdot 5$ \\
\hline & Controlled diet & 93 & 46.5 \\
\hline \multirow[t]{2}{*}{ Fasting blood sugar } & $<110 \mathrm{mg} / \mathrm{dL}$ & 89 & 44.5 \\
\hline & $\geq 110 \mathrm{mg} / \mathrm{dL}$ & 111 & 54.0 \\
\hline \multirow[t]{2}{*}{ Physical activity } & Not active & 118 & 59.0 \\
\hline & Active & 82 & 41.0 \\
\hline \multirow[t]{2}{*}{ Duration of illness } & $<5$ years & 77 & 38.5 \\
\hline & $\geq 5$ years & 123 & 61.5 \\
\hline \multirow[t]{3}{*}{ Peripheral neuropathy } & No Peripheral & 91 & $45 \cdot 5$ \\
\hline & Neuropathy & & \\
\hline & Peripheral Neuropathy & 109 & 54.5 \\
\hline
\end{tabular}

Table 2 shows the majority of the 200 study subjects aged $\geq 55$ years were 103 people (51.50\%). 132 people (66\%) were female. Subjects with married status were 190 people (95\%). Low-educated subjects were 121 people (60.50\%). Subjects who had income $<\operatorname{Rp} 1,800,000$ were 113 people
(56.50\%). Subjects with low health literacy were 110 people (55.00\%). 112 respondents (56.00\%) had low self-efficacy. As many as 116 (58.00\%) patients were disobedient to the medication. Subjects with uncontrolled diet were 107 people (53.50\%). Subjects with fasting blood sugar $\geq 110 \mathrm{mg} / \mathrm{dL}$ were 
111 people (54.0\%). The majority of low physical activity was 118 people (59.0\%). Subjects with duration of illness $\geq 5$ years were 123 people $(61.50 \%)$ and 109 people (55.50\%) experienced complications of peripheral neuropathy.

Table 3. Bivariate Analysis

\begin{tabular}{|c|c|c|c|c|c|c|c|c|}
\hline \multirow{3}{*}{ Variable } & \multicolumn{4}{|c|}{ Peripheral Neuropathy } & \multirow{2}{*}{\multicolumn{2}{|c|}{ Total }} & \multirow{3}{*}{$\mathbf{O R}$} & \multirow{3}{*}{$\mathbf{p}$} \\
\hline & \multicolumn{2}{|c|}{ No } & \multicolumn{2}{|c|}{ Yes } & & & & \\
\hline & $\mathbf{N}$ & \% & $\mathbf{N}$ & $\%$ & $\mathbf{N}$ & $\%$ & & \\
\hline \multicolumn{9}{|l|}{ Age } \\
\hline$<55$ years old & 68 & 70.1 & 29 & 29.9 & 97 & 100 & \multirow[t]{2}{*}{8.15} & \multirow[t]{2}{*}{$<0.001$} \\
\hline$\geq 55$ years old & 23 & $23 \cdot 3$ & 80 & 77.7 & 103 & 100 & & \\
\hline \multicolumn{9}{|l|}{ Education } \\
\hline Low & 28 & 23.1 & 93 & 76.9 & 121 & 100 & \multirow{2}{*}{0.07} & \multirow{2}{*}{$<0.001$} \\
\hline High & 63 & 79.7 & 16 & 20.3 & 79 & 100 & & \\
\hline \multicolumn{9}{|l|}{ High } \\
\hline$<\operatorname{Rp} 1,800,000$ & 21 & 18.6 & 92 & 81.4 & 113 & 100 & \multirow[t]{3}{*}{0.05} & \multirow[t]{3}{*}{$<0.001$} \\
\hline$\geq \operatorname{Rp} 1,800,000$ & 70 & 80.5 & 17 & 19.5 & 87 & 100 & & \\
\hline \multicolumn{7}{|l|}{ Health Literacy } & & \\
\hline Low & 14 & 12.7 & 96 & $87 \cdot 3$ & 110 & 100 & \multirow[t]{2}{*}{0.02} & \multirow[t]{2}{*}{$<0.001$} \\
\hline High & 77 & 85.6 & 13 & 14.4 & 90 & 100 & & \\
\hline \multicolumn{9}{|l|}{ Efficacy } \\
\hline Low & 15 & 13.4 & 97 & 86.6 & 112 & 100 & \multirow[t]{2}{*}{0.02} & \multirow[t]{2}{*}{$<0.001$} \\
\hline High & 76 & 86.4 & 12 & 13.6 & 88 & 100 & & \\
\hline \multicolumn{9}{|c|}{ Medication Adherence } \\
\hline Disobedient & 20 & 17.2 & 96 & 82.8 & 116 & 100 & \multirow[t]{2}{*}{0.03} & \multirow[t]{2}{*}{$<0.001$} \\
\hline Obedient & 71 & 84.5 & 13 & 15.5 & 84 & 100 & & \\
\hline \multicolumn{9}{|l|}{ Diet } \\
\hline Uncontrolled diet & 14 & 13.1 & 93 & 86.9 & 107 & 100 & \multirow[t]{2}{*}{0.03} & \multirow[t]{2}{*}{$<0.001$} \\
\hline Controlled diet & 77 & 82.8 & 16 & 17.2 & 93 & 100 & & \\
\hline Fasting blood sug & & & & & & & & \\
\hline$<110 \mathrm{mg} / \mathrm{dL}$ & 78 & 87.6 & 11 & 12.4 & 89 & 100 & 53.45 & $<0.001$ \\
\hline$\geq 110 \mathrm{mg} / \mathrm{dL}$ & 13 & 11.7 & 98 & 88.3 & 111 & 100 & & \\
\hline Physical activity & & & & & & & & \\
\hline Not active & 22 & 18.6 & 96 & 81.4 & 118 & 100 & 0.04 & $<0.001$ \\
\hline Active & 69 & 84.1 & 13 & 15.9 & 82 & 100 & & \\
\hline Duration of illne & & & & & & & & \\
\hline$<5$ years & 57 & 74.0 & 20 & 26.0 & 77 & 100 & 7.46 & $<0.001$ \\
\hline$\geq 5$ years & 34 & 34.0 & 98 & 89.0 & 123 & 100 & & \\
\hline
\end{tabular}

\begin{tabular}{|c|c|c|c|c|c|c|c|c|}
\hline \multirow{3}{*}{ Variable } & \multicolumn{4}{|c|}{ Peripheral Neuropathy } & \multirow{2}{*}{\multicolumn{2}{|c|}{ Total }} & \multirow{3}{*}{$\mathbf{O R}$} & \multirow{3}{*}{$\mathbf{p}$} \\
\hline & \multicolumn{2}{|c|}{ No } & \multicolumn{2}{|c|}{ Yes } & & & & \\
\hline & $\mathbf{N}$ & $\%$ & $\mathbf{N}$ & $\%$ & $\mathbf{N}$ & $\%$ & & \\
\hline \multicolumn{9}{|l|}{ Age } \\
\hline$<55$ years old & 68 & 70.1 & 29 & 29.9 & 97 & 100 & 8.15 & $<0.001$ \\
\hline$\geq 55$ years old & 23 & 23.3 & 80 & 77.7 & 103 & 100 & & \\
\hline \multicolumn{9}{|l|}{ Education } \\
\hline Low & 28 & 23.1 & 93 & 76.9 & 121 & 100 & 0.07 & $<0.001$ \\
\hline High & 63 & 79.7 & 16 & 20.3 & 79 & 100 & & \\
\hline \multicolumn{9}{|l|}{ High } \\
\hline$<\operatorname{Rp} 1,800,000$ & 21 & 18.6 & 92 & 81.4 & 113 & 100 & 0.05 & $<0.001$ \\
\hline \multicolumn{9}{|l|}{ Health Literacy } \\
\hline Low & 14 & 12.7 & 96 & 87.3 & 110 & 100 & 0.02 & $<0.001$ \\
\hline High & 77 & 85.6 & 13 & 14.4 & 90 & 100 & & \\
\hline \multicolumn{9}{|l|}{ Efficacy } \\
\hline Low & 15 & 13.4 & 97 & 86.6 & 112 & 100 & 0.02 & $<0.001$ \\
\hline High & 76 & 86.4 & 12 & 13.6 & 88 & 100 & & \\
\hline \multicolumn{9}{|c|}{ Medication Adherence } \\
\hline Disobedient & 20 & 17.2 & 96 & 82.8 & 116 & 100 & 0.03 & $<0.001$ \\
\hline Obedient & 71 & 84.5 & 13 & $15 \cdot 5$ & 84 & 100 & & \\
\hline \multicolumn{9}{|l|}{ Diet } \\
\hline Uncontrolled diet & 14 & 13.1 & 93 & 86.9 & 107 & 100 & 0.03 & $<0.001$ \\
\hline Controlled diet & 77 & 82.8 & 16 & 17.2 & 93 & 100 & & \\
\hline \multicolumn{9}{|c|}{ Fasting blood sugar } \\
\hline$<110 \mathrm{mg} / \mathrm{dL}$ & 78 & 87.6 & 11 & 12.4 & 89 & 100 & 53.45 & $<0.001$ \\
\hline$\geq 110 \mathrm{mg} / \mathrm{dL}$ & 13 & 11.7 & 98 & 88.3 & 111 & 100 & & \\
\hline \multicolumn{9}{|l|}{ Physical activity } \\
\hline Not active & 22 & 18.6 & 96 & 81.4 & 118 & 100 & 0.04 & $<0.001$ \\
\hline Active & 69 & 84.1 & 13 & $15 \cdot 9$ & 82 & 100 & & \\
\hline \multicolumn{9}{|c|}{ Duration of illness } \\
\hline$<5$ years & 57 & 74.0 & 20 & 26.0 & 77 & 100 & 7.46 & $<0.001$ \\
\hline$\geq 5$ years & 34 & 34.0 & 98 & 89.0 & 123 & 100 & & \\
\hline
\end{tabular}

Table 3 shows the results of the bivariate analysis of factors affecting peripheral neuropathy in type $2 \mathrm{DM}$ patients including age $\geq 55$ years $(\mathrm{OR}=8.15 ; \mathrm{p}$ $<0.001)$. Education $\geq$ senior high school $(\mathrm{OR}=0.07 ; \mathrm{p}<0.001)$. Income $\geq \mathrm{Rp} 1,800,-$ ooo (OR=0.05; $\mathrm{p}<0.001)$. High health literacy $(\mathrm{OR}=0.02 ; \mathrm{p}<0.001)$. High self-effi-

\section{Bivariate Analysis}

Table 3 shows the results of the chi-square test between the effects of age, income, health literacy, self-efficacy, medication adherence, diet, physical activity, duration of illness, and fasting blood sugar with peripheral neuropathy.

cacy $(\mathrm{OR}=0.02 ; \mathrm{p}<0.001)$. Medication adherence $(\mathrm{OR}=0.03 ; \mathrm{p}<0.001)$. Controlled diet $(\mathrm{OR}=0.03 ; \mathrm{p}<0.001)$. Fasting blood sugar $\geq 110 \mathrm{mg} / \mathrm{dL}(\mathrm{OR}=53.45 ; \mathrm{p}$ $<0.001)$. Active physical activity $(\mathrm{OR}=$ 0.04; $\mathrm{p}<0.001)$. Duration of illness $\geq 5$ years $(\mathrm{OR}=7.46 ; \mathrm{p}<0.001)$. 


\section{Multiple Logistic Regression}

The results of multiple logistic regression analysis are shown in table 4 . Table 4 shows the effect of age on peripheral neuropathy.

Table 4. Multiple Logistic Regression
Age $\geq 55$ years had logodd to increase the risk of peripheral neuropathy by 3.61 units compared to age $<55$ years $(\mathrm{b}=3.61$; $\mathrm{CI}$ $95 \%=1.51$ to $5.70 ; \mathrm{p}=0.001$ ).

\begin{tabular}{|c|c|c|c|c|}
\hline \multirow{2}{*}{ Variables } & \multirow{2}{*}{ b } & \multicolumn{2}{|c|}{$95 \% \mathrm{CI}$} & \multirow[b]{2}{*}{$\mathbf{p}$} \\
\hline & & Lower Limit & Upper Limit & \\
\hline Age $\geq 55$ years & 3.61 & 1.51 & 5.70 & 0.001 \\
\hline Education $\geq$ senior high school & -2.41 & $-4 \cdot 31$ & -0.51 & 0.013 \\
\hline Income $\geq \operatorname{Rp~} 1,800,000$ & -1.58 & -3.12 & -0.04 & 0.044 \\
\hline High health literacy & -1.52 & -3.18 & 0.14 & 0.073 \\
\hline High self-efficacy & -1.67 & -3.26 & -0.07 & 0.040 \\
\hline High medication adherence & -2.34 & -4.13 & -0.56 & 0.010 \\
\hline Controlled diet & -1.89 & -3.64 & -0.14 & 0.034 \\
\hline High physical activity & -2.33 & -4.17 & -0.49 & 0.013 \\
\hline Duration of illness $\geq 5$ years & 2.78 & 0.51 & 5.04 & 0.016 \\
\hline $\begin{array}{l}\text { Fasting blood sugar } \geq 110 \mathrm{mg} / \mathrm{dL} \\
\text { N observation }=200 \\
\text { Likelihood }=-26.35182\end{array}$ & 1.64 & -0.01 & 3.03 & 0.052 \\
\hline
\end{tabular}

There was an effect of education level on peripheral neuropathy. High education $\geq$ senior high school had logodd to decrease the risk of peripheral neuropathy by 2.41 units compared to low education <senior high school $(b=-2.41 ; 95 \% \mathrm{CI}=-4.31$ to -0.51 ; $\mathrm{p}=0.013$ ).

There was an effect of income on peripheral neuropathy. Income $\geq 1,800,000$ had logodd to decrease the risk of peripheral neuropathy by 1.58 units compared to income $<1,800,000(\mathrm{~b}=-1.58 ; 95 \% \mathrm{CI}=-$ 3.12 to $-0.04 ; \mathrm{p}=0.044)$.

There was an effect of health literacy on peripheral neuropathy. High health literacy had logodd to decrease the risk of peripheral neuropathy by 1.52 units compared to low health literacy $(b=-1.52 ; 95 \% \mathrm{CI}=$ 3.18 to $0.14 ; p=0.073$ ).

There was an effect of self-efficacy on peripheral neuropathy. High self-efficacy had logodd to decrease the risk of peripheral neuropathy by 1.67 units compared to low self-efficacy $(b=-1.67 ; 95 \% \mathrm{CI}=-3.26$ to -0.07; $\mathrm{p}=0.040$ ).

There was an effect of medication adherence on peripheral neuropathy. High medication adherence had logodd to decrease the risk of peripheral neuropathy by 2.34 units compared to low medication adherence $(b=-2.34 ; 95 \% \mathrm{CI}=-4.13$ to -0.56 ; $\mathrm{p}=0.010$ ).

There was an effect of diet on peripheral neuropathy. Controlled diet had logodd to decrease the risk of peripheral neuropathy by 1.89 units compared to uncontrolled diet $(b=-1.89 ; 95 \% \mathrm{CI}=-3.64$ to -0.14; $\mathrm{p}=0.034)$.

There was an effect of physical activity on peripheral neuropathy. High physical activity had logodd to decrease the risk of peripheral neuropathy by 2.33 units compared to low physical activity $(b=-2.33$; 95\% $\mathrm{CI}=-4.17$ to $-0.49 ; \mathrm{p}=0.013$ ).

There was an effect of duration of illness on peripheral neuropathy. Duration of illness $\geq 5$ years had logodd to increase the risk of peripheral neuropathy by 2.78 units compared to duration of illness $<5$ years $(b=2.78 ; 95 \% \mathrm{CI}=0.51$ to $5.04 ; \mathrm{p}=$ o.016).

There was an effect of fasting blood sugar on peripheral neuropathy. Fasting blood sugar $\geq 110 \mathrm{mg} / \mathrm{dL}$ had logodd to 
increase the risk of peripheral neuropathy by 1.64 units compared to activity and fasting blood sugar $<110 \mathrm{mg} / \mathrm{dL}(\mathrm{b}=1.64$; $95 \% \mathrm{CI}=-0.01$ to 3.03 ; $\mathrm{p}=0.052$ ).

\section{DISCUSSION}

\section{The effect of duration of illness on} peripheral neuropathy

This result of the study is in line with the result of a study conducted by Khawaja et al. (2018) that patients with type 2 diabetes mellitus with duration of diabetes $\geq 5$ years tend to be at risk of having peripheral neuropathy compared to patients with type 2 diabetes mellitus $<5$ years. Jaiswal et al. (2017) state that the longer the duration of illness in patients with type 2 diabetes mellitus, the greater the risk of peripheral neuropathy. It occurs because patients with duration of illness $<5$ years can maintain blood glucose level better than patients with type 2 diabetes mellitus $\geq 5$ years.

Prolonged hyperglycemia can reduce glycolysis in cells, increase oxidative stress and stimulate other pathways that cause nerve and endothelial dysfunction to blood vessels (Nisar et al., 2015)

Patients who have been diagnosed with type 2 diabetes mellitus for a long time have felt tired to do self-care action; in addition, the intention to do healthy behaviors has also decreased (Pranoto, 2017).

\section{The effect of age on peripheral neuropathy}

This result of the study is in line with the result of a study conducted by Karki et al. (2018) that the frequency of neuropathy at $>55$ years of age is higher than $<40$ years of age. Age over 60 years also tend to have peripheral neuropathy and diabetic foot ulcers (Kisozi et al., 2017).

According to Suwannaphant et al. (2017), the prevalence of diabetes mellitus tends to be experienced in people aged 51 years to 65 years. It occurs because the function of beta cells in the pancreas decrease with age. At the age of 40 years, people generally have a faster physiological decline (Babazadeh et al., 2017).

\section{The effect of fasting blood sugar on peripheral neuropathy}

The result of this study is in line with the result of a study conducted by Garoushi et al. (2019) that the higher the fasting blood sugar levels of diabetic patients, the greater the risk of peripheral neuropathy. It is 3.51 times greater than diabetic patients who have normal fasting blood sugar levels. However, normal fasting blood sugar can reduce the risk of peripheral neuropathy by 5 to 9 percent (Pop-Busui et al., 2017).

It occurs because persistent hyperglycemia leads to an increase in cytosolic and mitochondrial reactive oxygen species (ROS). In addition, it supports the deregulation of antioxidant defenses that are able to activate various metabolic pathways such as polyol, hexosamine, protein kinase C, Advanced Glycation End Products, glycosylation, and glycolysis. The active metabolic pathways support the occurrence of oxidative damage which ultimately leads to the occurrence of large-fiber damage specifically the nerves that are in the distal part (Sifuentes Franco et al., 2017)

\section{The effect of medical adherence on peripheral neuropathy}

This result of the study is in line with the result of a study conducted by Kassahun et al. (2016) that there is an association between medication adherence and blood sugar levels. High medication adherence will make blood sugar levels be controlled.

The use of controlled insulin and antiglycemic drugs reduces the chance of peripheral neuropathy by 3.93 times compared to the use of uncontrolled drugs. The role of intensive glycemic control in prevention and controlled treatment makes the 
chances of peripheral neuropathy lower (Wang et al., 2014). Controlling hyperglycemia through medication is the only way to reduce and prevent neuropathy from getting worse (Karki et al., 2018)

\section{The effect of diet on peripheral neuropathy}

This result of the study is in line with the result of a study conducted by Meng et al (2017) that low-carbohydrate diet interventions significantly reduce the concentration of blood sugar levels in the body. Dietary pattern by consuming more vegetables and fruits on the daily menu is one of the ways to improve glycemic control in patients with diabetes mellitus (Jiang et al., 2012).

According to Buscemi et al. (2013), the dietary principle for people with diabetes mellitus is to reduce and regulate carbohydrate consumption;therefore, it does not become a burden for the mechanism in the regulation of blood sugar levels. Eating management (diet) is a major component of the successful management of diabetes mellitus (Buscemi et al., 2013)

\section{The effect of physical activity on peripheral neuropathy}

According to van Dijk and van Loon (2015), physical activity carried out every day for 30 minutes is much more effective in controlling blood sugar levels than physical activity for 60 minutes/day which is done at certain times. Activities carried out consistently can provide benefits in maintaining good glycemic control of peripheral neuropathy (Yates et al., 2015).

According to Khawaja et al. (2018), physical activity will affect several mechanisms such as microvascular dilatation, attenuation of oxidative stress, and the release of neurotropic mediators which has role as modulators of inflammation and insulin sensitizers.

\section{The effect of health literacy on peripheral neuropathy}

Based on the result of a study conducted by Bailey et al. (2014), there is an association between health literacy and knowledge. Higher health literacy is associated with greater knowledge about diabetes. Health literacy is useful for understanding, assessing, and applying health information obtained.

Diabetes patients with low levels of health literacy are difficult to navigate a large number of recommendations regarding diet and physical activity behavior (Friis et al., 2016). The higher the health literacy of a patient with diabetes mellitus, the higher the health management behavior of a patient with diabetes mellitus (Chahardahcherik et al., 2018). The management of diabetes self-care includes blood glucose monitoring, physical activity, interpretation of laboratory data, modification of food intake, and medication administration (Huang et al., 2018).

\section{The effect of self-efficacy on peri- pheral neuropathy}

This result of the study is in line with the result of a study conducted by Tharek et al. (2018) that patients who have strong selfefficacy will increase self-care behavior by 0.53 times higher than patients with poor self-efficacy. The higher the one's selfefficacy, the better the self-care behavior; therefore, the risk of peripheral neuropathy is smaller (Masoompour et al., 2017).

Strong self-efficacy will make someone more obedient to the complications prevention behaviors. In addition, someone also believes in managing diabetes mellitus and believes that the management of diabetes mellitus carried out will produce a good effect on the disease (Prasetyowati et al., 2018). 


\section{The effect of education level on peripheral neuropathy}

This result of the study is supported by a study conducted by Devarajooh dan Chinna (2017), that there is an association between education level and self-efficacy. Someone with a high education level has better selfefficacy compared to someone with basic education towards the practice of self-care of diabetes mellitus.

The higher the education level, the better the ability to do glycemic control. It is because higher education increases health literacy and better knowledge about diabetes (Olesen et al., 2017). Diabetes mellitus patients with a high level of education are more likely to do physical activity regularly compared to patients with a low level of education (Steele et al., 2017)

Someone with a high level of education has a better awareness of diabetes mellitus complications such as peripheral neuropathy. Patients with higher education have better and correct diabetes management in using oral antidiabetic and insulin (Gedik and Kocoglu, 2018). In addition, someone will get better income which is closely related to the diet of diabetes mellitus (Budiarti et al., 2017)

\section{The effect of income on peri- pheral neuropathy}

This result of the study is in line with the result of a study conducted by Babazadeh et al. (2017), that there is a significant association between family income and diabetes mellitus complications. The higher income will decrease the risk of complications such as peripheral neuropathy.

Low income is also closely related to the low utilization of health services. Besides, patients with peripheral neuropathy also need more health care costs than diabetes mellitus patients without complications (Juster-Switlyk and Smith, 2016).
According to Lee et al. (2011), individuals from low socio-economic status more often reduce discretion in fulfilling their food needs. This deficiency causes food insecurity in the family.

At low income levels, diabetes mellitus patients feel unable to meet their calorie needs. Therefore, they lose weight. As a result, they move to the cheaper foods. Combining higher-cost items, such as vegetables are more difficult because the food budget is increasingly insufficient. Maintaining a healthy diet within financial constraints need more time, motivation, planning, and knowledge (Seligman et al., 2012).

Peripheral neuropathy is directly affected by age, duration of illness, fasting blood sugar. Besides, peripheral neuropathy is indirectly affected by education, income, self-efficacy, diet, medication adherence, physical activity, and health literacy.

AUTHOR CONTRIBUTION
Akhmad Azmiardi played a role in collect-
ing the data, processing the data, and
compiling the article. Didik Tamtomo
helped in the discussion of peripheral
neuropathy and revised the article. Bhisma
Murti helped in developing the conceptual
framework, analyzing the data, interpreting
the results of the analysis, and revising the
article.

FUNDING AND SPONSORSHIP

This study used independent fund.

\section{CONFLICT OF INTEREST}

This is no conflict of interest.

\section{ACKNOWLEDGEMENT}

We give the best gratitude to the director of the hospital in Surakarta City for allowing 
us to use the hospital as a research site. We also give the gratitude to the nurses in internal medicine polyclinic for helping us to collect the data.

\begin{tabular}{c}
\hline REFERENCE \\
\hline Babazadeh T, Dianatinasab M, Daemi A, \\
Nikbakht HA, Moradi F, Ghaffari- \\
Fam S (2017). Association of self-care \\
behaviors and quality of life among \\
patients with type 2 diabetes mellitus: \\
Chaldoran County, Iran. Diabetes \\
Metab J, 41(6): 449-456. https://- \\
doi.org/10.4093/dmj.2017.41.6.449
\end{tabular}

Bailey SC, Brega AG, Crutchfield TM, Elasy T, Herr H, Kaphingst K, et al. (2014). Update on health literacy and diabetes. Diabetes Educ, 40(5), 581604. https://doi.org/10.1177/0145721714540220

Budiarti E, Tamtomo DG, Adriani RB (2017). Path analysis on the biopsychosocial determinants of type 2 diabetes mellitus and depression at Dr. Moewardi Hospital, Surakarta. J Epidemiol Public Health, 03(01), 114. https://doi.org/10.26911/jepublichealth.2018.03.01.01

Buscemi S, Nicolucci A, Mattina A, Rosafio G, Massenti FM, Lucisano G, et al. (2013). Association of dietary patterns with insulin resistance and clinically silent carotid atherosclerosis in apparently healthy people. Eur. J. Clin. Nutr, 67(12): 1284-1290. https://doi.org/10.1038/ejcn.2013.172

Callaghan BC, Cheng HT, Stables CL, Smith AL, Feldman EL (2012). Diabetic neuropathy: Clinical manifestations and current treatments. Lancet, 11(6): 521-534. https://doi.org/10.1016/S1474-4422(12)70065-0

Chahardah-cherik S, Gheibizadeh M, Jahani $S$ (2018). The relationship between health literacy and health promoting behaviors in patients with type 2 diabetes, Int $\mathrm{J}$ Community Based Nurs Midwifery, 6(1), 65-75

Deli G, Bosnyak E, Pusch G, Komoly S, Feher G (2013). Diabetic neuropathies: Diagnosis and management. Neuroendocrinology, 98(4), 267-280. https://doi.org/10.1159/oo0358728

Devarajooh C, Chinna K (2017). Depression, distress and self-efficacy: The impact on diabetes self-care practices. PloS One, 12(3): e0175096. https://doi.org/10.1371/journal.pone.0175096

Dinas Kesehatan Kota Surakarta. (2018). Profil kesehatan kota Surakarta tahun 2017. Dinas Kesehatan Kota Surakarta.

Dinkes Jateng. (2017). Profil kesehatan provinsi Jawa Tengah 2017. Dinkes Jateng. Retrieved from https://doi.org/10.5606/totbid.dergisi.2012.10

Feldman EL, Nave KA, Jensen TS, Bennett DLH (2017). New horizons in diabetic neuropathy: Mechanisms, bioenergetics, and pain. Neuron, 93(6), 12961313. https://doi.org/10.1016/j.neuron.2017.02.005

Forbes JM, Cooper ME (2013). Mechanisms of diabetic complications. Am. J. Physiol, 93(1): 137-188. https://doi.org/10.1152/physrev.00045.2011

Friis K, Vind BD, Simmons RK, Maindal HT (2016). The relationship between health literacy and health behaviour in people with diabetes: A Danish Population-Based Study. J Diabetes Res, 1-7. https://doi.org/10.1155/20$16 / 7823130$

Garoushi S, Johnson MI, Tashani OA (2019). A cross-sectional study to estimate the point prevalence of painful diabetic neuropathy in Eastern Libya. BMC Public Health, 19(1): 78. https://doi.org/10.1186/s12889-018-6374- 


\section{9}

Gedik S, Kocoglu D (2018). Self-efficacy level among patients with type 2 diabetes living in rural areas. Rural Remote Health, 18(1), 4262. https://doi.org/10.22605/RRH4262

Huang YM, Shiyanbola OO, Smith PD (2018). Association of health literacy and medication self-efficacy with medication adherence and diabetes control. Patient Prefer Adher, 12, 793-802. https://doi.org/10.2147/PPA.S153312.

International Diabetes Federation (IDF) (2017). Eighth edition 2017. IDF Diabetes Atlas, 8th edition. https://doi.org/http://dx.doi. org/10.1016/So140-6736(16)31679-8.

Jaiswal M, Divers J, Dabelea D, Isom S, Bell RA, Martin CL, et al. (2017). Prevalence of and risk factors for diabetic peripheral neuropathy in youth with type 1 and type 2 diabetes: SEARCH for diabetes in youth study. Diabetes Care, 40(9): 1226-1232. https://doi.org/10.2337/dc17-0179

Jiang J, Qiu H, Zhao G, Zhou Y, Zhang Z, Zhang $\mathrm{H}$, et al. (2012). Dietary fiber intake is associated with HbA1c level among prevalent patients with type 2 diabetes in Pudong New Area of Shanghai, China. PLoS One, 7(10): e46552. https://doi.org/10.1371/journal.pone.0046552

Juster-Switlyk K, Smith AG (2016). Updates in diabetic peripheral neuropathy. F100oRes, 5. Retrieved from https://doi.org/10.12688/f10ooresearch.7898.1

Karki D, Nagila A, Dhakal N, Chhetri S (2018). Prevalence of peripheral neuropathy in diabetes mellitus and its association with therapy, ethnicity and duration of diabetes mellitus. J. Med. Sci, 10(1): 72-76. https://doi.- org/10.3126/ajms.v10i1.21743

Kassahun A, Gashe F, Mulisa E, Rike WA (2016). Nonadherence and factors affecting adherence of diabetic patients to anti-diabetic medication in Assela General Hospital, Oromia Region, Ethiopia. J. Pharm. Bioallied Sci, 8(2): 124-129. https://doi.org/10.4103/0975-7406.171696

Khawaja N, Abu-Shennar J, Saleh M, Dahbour SS, Khader YS, Ajlouni KM (2018). The prevalence and risk factors of peripheral neuropathy among patients with type 2 diabetes mellitus; the case of Jordan. Diabetol Metab Syndr, 10(8). https://doi.org/10.1186/s13098-018-0309-6

Kisozi T, Mutebi E, Kisekka M, Lhatoo S, Sajatovic M, Kaddumukasa M, et al. (2017). Prevalence, severity and factors associated with peripheral neuropathy among newly diagnosed diabetic patients attending Mulago hospital: a cross-sectional study. Afr Health Sci, 17(2), 463. https://doi.org/10.4314/ahs.v17i2.21

Lee TC, Glynn RJ, Peña JM, Paynter NP, Conen D, Ridker PM, et al. (2011). Socioeconomic status and incident type 2 diabetes mellitus: data from the Women's Health Study. PLoS One, 6(12): e27670. https://doi.org/10.1371/journal.pone.0027670

Masoompour M, Tirgari B, Ghazanfari Z (2017). The Relationship between health literacy, self-efficacy, and selfcare behaviors in diabetic patients. Iran J Basic Med Sci, 7(3), 17-25. https://doi.org/10.22038/EBCJ.2017.24826.1551

Meng Y, Bai H, Wang S, Li Z, Wang Q, Chen L (2017). Efficacy of low carbohydrate diet for type 2 diabetes mellitus management: A systematic review and meta-analysis of rando- 
mized controlled trials. Diabetes Res Clin Pract, 131, 124-131. https://doi.org/10.1016/J.DIABRES.2017.07.006

Nisar MU, Asad A, Waqas A, Ali N, Nisar A, Qayyum MA, et al. (2015). Association of diabetic neuropathy with duration of type 2 diabetes and glycemic control. Cureus, 7(8), e302. https://doi.org/10.7759/cureus.302

Olesen K, F Reynheim AL, Joensen L, Ridderstråle M, Kayser L, Maindal HT, et al. (2017). Higher health literacy is associated with better glycemic control in adults with type 1 diabetes: a cohort study among 1399 Danes. BMJ Open Diabetes Res Care 5(1), eoo0437. https://doi.org/10.1136/bmjdrc-2017-000437

Papanas N, Ziegler D (2015). Risk factors and comorbidities in diabetic neuropathy: An Update 2015. Rev Diabet Stud, 12(1-2): 48-62. https://doi.org/10.1900/RDS.2015.12.48

Pop-Busui R, Boulton AJM, Feldman EL, Bril V, Freeman R, Malik RA, et al. (2017). Diabetic neuropathy: A position statement by the American Diabetes Association. Diabetes Care, 40(1): 136-154. https://doi.org/10.2337/dc16-2042

Pranoto HP, Tamtoto D, Murti B (2017). The roles of medical doctor and family on patient healthbehavior in controlling $\mathrm{HbA1C}$ level among patients with type 2 diabetes mellitus at Dr. Moewardi Hospital. Indones J Med, 02(01), 21-34. https://doi.org/10.26911/theijmed.2017.02.01.03

Prasetyowati U, Tamtoto D, Murti B (2018). Path Analysis: factors associated with self preventive care among patients with type 2 diabetes mellitus in Surkarta. J Health Promot Behav, 03(02): 86-93. https://doi.org/10.26911/thejhpb.2018.03.02.01
Seligman HK, Jacobs EA, López A, Tschann J, Fernandez A (2012). Food insecurity and glycemic control among lowincome patients with type 2 diabetes. Diabetes Care, 35(2): 233-238. https://doi.org/10.2337/dc11-1627

Sifuentes-Franco S, Pacheco-Moisés FP, Rodríguez-Carrizalez AD, MirandaDíaz AG (2017). The role of oxidative stress, mitochondrial function, and autophagy in diabetic polyneuropathy. J. Diabetes Res. 1673081. https://doi.org/10.1155/2017/1673081.

Soewondo P, Ferrario A, Tahapary DL (2013). Challenges in diabetes management in Indonesia: a literature review. Global Health, 9: 63. https://doi.org/10.1186/1744-8603-9-63

Steele CJ, Schöttker B, Marshall AH, Kouvonen A, O’Doherty MG, Mons U, et al. (2017). Education achievement and type 2 diabetes-what mediates the relationship in older adults? Data from the ESTHER study: a population-based cohort study. BMJ Open, 7(4), e013569. https://doi.org/10.1136/bmjopen-2016-013569

Suwannaphant K, Laohasiriwong W, Puttanapong N, Saengsuwan J, Phajan T (2017). Association between socioeconomic status and diabetes mellitus: the national socioeconomics survey, 2010 and 2012. J Clin Diagn Res, 11(7), LC18-LC22. https://doi.org/10.7860/JCDR/2017/28221.10286

Tharek Z, Ramli AS, Whitford DL, Ismail Z, Mohd Zulkifli M, Ahmad Sharoni SK, et al. (2018). Relationship between self-efficacy, self-care behaviour and glycaemic control among patients with type 2 diabetes mellitus in the Malaysian primary care setting. BMC Fam Pract, 19(1): 39. https://doi.org/10.1186/s12875-018-0725-6

van Dijk JW, van Loon LJC (2015). Exer- 
cise strategies to optimize glycemic control in type 2 diabetes: a continuing glucose monitoring perspective. Diabetes Spectr, 28(1): 24-31. https://doi.org/10.2337/diaspect.28.1.24

Vinik AI, Nevoret ML, Casellini C, Parson H (2013). Diabetic neuropathy. Endocrinol Metab Clin North Am, 42(4), 747787. https://doi.org/10.1016/j.ecl.2013.06.001.

Wang DD, Bakhotmah BA, Hu FB, Alzahrani HA (2014). Prevalence and correlates of diabetic peripheral neuropathy in a Saudi Arabic Population: A
Cross-Sectional Study. PLoS One, 9(9). https://doi.org/10.1371/journal.pone.0106935.

Yates T, Griffin S, Bodicoat DH, Brierly G, Dallosso H, Davies MJ, et al.. (2015). Promotion of physical activity through structured education with differing levels of ongoing support for people at high risk of type 2 diabetes (PROPELS): Study protocol for a randomized controlled trial. Trials, 16: 289. https://doi.org/10.1186/s13o63-015-0813-z 